\title{
A History of the Cell Theory of Cancer Metastasis
}

\author{
By Wilson I.B. Onuigbo
}

In 1908 RusselL wrote in his Aberdeen doctorate thesis:

"The history of cancer is practically the history of medicine, and along with other diseases it had to pass through the stage of pure theorising which characterised the Medical Renaissance in Europe. In this period, no new knowledge was added to that of GaLen and Hippocrates, and this was scarcely to be expected since cancer is essentially a cellular disease, and it was necessary for further progress to take place, that the minute structures of normal tissues should first become known. With the evolution of the microscope in the nineteenth century, at first botanists and later zoologists were able to observe carefully the histological structure of living tissues, and this served as a basis on which the embryologists and the pathologists were respectively able to follow out in detail the normal and abnormal processes of growth. These observations culminated in the work of REMAK on the germlayers, and in VIRchow's Cellular Pathology."1

Recently, WILDER drew a historical sketch of the development of our knowledge of cancer metastasis. ${ }^{2} \mathrm{He}$ did not, however, include the cell theory of this phenomenon in his account. Ackerknecht, on the other hand, contributed in his general notes on cancer a brief account of the change from the old humoralistic to the present solidistic (cellular) concept of cancer metastasis. ${ }^{3}$ This conceptual transformation took time. Let us trace its origins and gradual acceptance.

We go first to the late eighteenth century when the acme of humoral metastasis was reached. We find LEAKE saying in 1777, "When the mass of blood, the very foundation from which both life and health proceed, is unfortunately tainted and corrupted with their poisonous fluid, the whole constitution is rendered sickly and diseased, and the cancerous matter frequently fixes upon some other glandular part; so that what was at first

1 B. R. G. Russell, Studies on Experimental Cancer, M.D. Thesis, Aberdeen University, 1908, p. 1.

${ }^{2}$ J. Mt. Sinai Hosp. 23 (1956) 728.

${ }^{3}$ Med. Hist. 2 (1958) 114. 
only local, now becomes a universal disease, and like a pestilential blight, overspreads and lays waste the whole bodily frame." 4 JoHN HUNTER was among those who held the humoral concept of cancer spread. ${ }^{5}$ Before long, however, the outlook was to change. "Of late", wrote LATtA in 1793, "a new theory has been mentioned, viz. that the virus of the cancer was contained in the crooked veins which surround it, and ... that (it) is by means of these that the cancer spreads its corroding ichor through the neighbouring parts". ${ }^{6}$ Thus, it would seem that by the 1790 's there was already some groping after the identity of the material responsible for the spread of cancer.

It seems to me that surgeons were probably the first to realise that whatever brought about metastasis was quite minute. GuY, a surgeon in Bath, surmised in 1778 that "if any of the diseased, or contaminated parts remain after the operation, even to the degree of a fibre, it will reassume (from its morbid disposition) a fresh disease, the same as at first ..."7 Burvs, a lecturer in anatomy and surgery in the University of Glasgow, affirmed in 1811, "Experience daily proves, that if the smallest particle of morbid matter be left behind, the diseased action spreads from it, as from a centre ..."8 A decade later, DAwson declared:

"When the excision of the cancerous part is practicable, and safely practicable, the knife should be employed, and the whole of it ought to be taken away, so as not to leave an atom of the disease." 9

With the ascendancy of the microscope as a research tool in the 1830's, the minute structure of living tissues soon became apparent. The next step, which was quickly taken by MüLLER, ${ }^{10}$ was to elucidate the structure of

4 J. Leake, Medical Instructions towards the Prevention, and Cure of Chronic and Slow Diseases Peculiar to Women, London 1777, p. 110.

${ }^{5}$ The Works of John Hunter, ed. by J. F. Palmer, London 1835, vol. 1, p. 620. JoHN HUNTER's lectures, which were delivered in the years 1786 and 1787, were "printed from a very full and accurate copy, taken in short-hand by Mr. NATHaniel Rumsey of Chesham."

B J. Latta, A Practical System of Surgery, Edinburgh 1793, vol. 1, p. 152.

${ }^{7}$ M. GuY, A Treatise on Causes and Effects of Scirrhous Tumours and Cancers, Bath 1778, p. 14.

8 A. Bunns, Observations on the Surgical Anatomy of the Head and Neck, Edinburgh 1811, p. 224.

9 G. P. Dawson, A Nosological Practice of Physic, Embracing Physiology, London 1824, p. 278.

10 J. MüLLER, On the Nature and Structural Characteristics of Cancer, and of Those Morbid Growths Which May Be Confounded with It, trad. by C. West, London 1840, p. 9. 
tumors. Müller, indeed, took a further step when he made not only noteworthy inferences but also references to the literature:

"The manner in which the carcinomatous dyscrasia becomes developed from a merely local disposition transcends our researches. It can, however, be easily understood, that, when once cells with a productive tendency have been formed, the reception of the germinal nuclei into the circulation may determine their distribution to some part predisposed to receive them, and may thus give rise to the formation of secondary tumors. How far the appearance of masses of fungus medullaris within the cavities of the large vessels, and especially of veins, which Sir A. Cooper, M. Cruveilhier, Dr. CARswell, and others, have observed, is connected with this circumstance, must still be a matter of doubt, for it has not yet been determined with certainty whether there exists any organic connexion between these masses and the vessels in which they are contained. No opportunity has occurred to the author for putting this to the test of accurate exam'n." 11

Despite MÜLLER's reservations, Watson of King's College, London, was prompted by his writings to state with confidence in 1843 that the question of the spread of cancer "admits of a distinct reply", namely, "it is by the transference of certain of these cells and granules from the original tumour that a crop of secondary tumours are sown in remote parts of the body." 12 Shortly before, WALSHE was also satisfied that "the micrography of cancer shows that the translation and deposition of a few cells only from the original nidus might lead to the development of the largest mass; each cell is in itself the possible embryo of a tumour." 13

We turn next to animal experiments. The tumour transplantation experiments of PeYrilhe gained the prize given by the Academy of Sciences at Lyons for the best dissertation on cancerous diseases in the year 1775 . He took about two drachms of cancerous matter from a diseased breast and injected it into a small wound made on the back of a dog. We learn that after a few days the animal's "whole body, from the head to the tail, became emphysematous, from all of which Mr. Peyrilhe concludes it to be at least very probable that the cancerous virus is of a putrid nature." 14 The next

11 Ibid. p. 89.

12 T. Watson, Lectures on the Principles and Practice of Physic, London 1843, pp. 206-207.

${ }^{13}$ W. H. Walshe, The Cyclopedia of Practical Surgery, ed. by W. B. Costello, London 1841, vol. 1, p. 620 .

${ }^{14}$ See Review in Medical and Philosophical Commentaries by a Society in Edinburgh, London 1775, vol. 3, pp. 388-391. 
epochal experiment was that of LANGENBECK who was struck by the microscopical structure of cancer cells found in the blood of persons dying of the disease. He obtained cancerous matter from a patient with uterine cancer and mixed it with defibrinated blood from a dog. Then, he injected this mixture into the femoral vein of the same dog. The dog was killed after two months. In the middle lobe of its right lung was found a circumscribed tumour "having all the characters of a carcinomatous tumour." 15 On the strength of this evidence, STILlÉ concluded that metastasis was due to "the absorption of cancer cells." 16 Other contemporaries, on the contrary, contested the validity of this experiment. ${ }^{17}$

During the 1850's it became common for writers to hold both the humoral and the cellular concepts of metastasis. ${ }^{18}$ To quote Paget:

"We need not assume that corpuscles of pus or cancer, or any kinds of germs already formed, must be thus carried for the multiplication or dissem'n of disease. A rudimental liquid, an unformed cancerous blastema, mingled with the blood, may be as effectual as any germs; and must almost necessarily be assumed, in the explanation of cases in which the dissem'n takes place, not in the lungs or liver but in organs beyond them in the course of the circulation." 19

In this connection, it is a paradox, in my view, ${ }^{20}$ that VIRCHOw himself did not lend the weight of his opinion to the cell theory of metastasis. Other authorities like Henoch of Germany and BenNetT of Scotland were also not convinced by the evidence in support of the cellular basis of metastasis. ${ }^{21}$

As we have seen, by 1860 the problem of the nature of the material that gave rise to metastases had been approached from a number of anglessurmise, microscopy, and experimentation. In the years ahead microscopy

15 Edinburgh Med. Surg. J. 55 (1841) 251.

${ }^{16}$ A. StiLlé, Elements of General Pathology, Philadelphia 1848, p. 461.

17 W. H. WALShe, The Nature and Treatment of Cancer, London 1846, pp. 144-145;

J. H. Bennetr, On Cancerous and Cancroid Growths, Edinburgh 1849, p. 210.

${ }^{18}$ Brit. Foreign Med.-Chir. Rev. 18 (1856) 509; Glasgow Med.J. 4 (1857) 415; C. RокITansky, A Manual of Pathological Anatomy, trad. by W. E. SwaIne, London 1854, vol. 1, p. 256.

19 J. PAget, Lectures on Surgical Pathology, London 1853, vol. 2, p. 580.

${ }^{20}$ W. I. B. Onuigbo, The Paradox of Virchow's Views on Cancer Metastasis, Bull. Hist. Med., in Press.

${ }^{21}$ Brit. Foreign Med.-Chir. Rev. 14 (1854) 163; J. H. Bennett, Clinical Lectures on the Principles and Practice of Medicine, Edinburgh 1858, 2nd ed., p. 214. 
was instrumental in moulding opinion. The fact that cancer cells could be seen in the vessels connected with the parent tumour was impressive. Jones reasoned that from such veins "the particles which may become detached, and carried along in the blood, will give rise to secondary formations ..." 22 With regard to the lymph vessels, WoodwaRD avowed that his own studies were in strict accordance with those of other workers who had seen in these vessels cancer "cylinders" extending in the form of networks. ${ }^{23}$ "Microscopists", as a reviewer affirmed in 1872, "have discovered an almost invariable similarity between primary cancers and their secondary growths, whether these be in lymphatic glands or in distant parts of the body; and this similarity has led them to believe ... that secondary tumours are always the offspring of elements derived from the parent growth, and transmitted bodily therefrom, through the medium of the blood, or some other available channel." 24

The novel animal experiments of CoнNHeIm in all probability finally tipped the scale in favour of the cell theory, for he succeded in propagating periosteum into the jugular vein of the hen. "This," conceded Coats in 1878, "seems to show that an embolus from a tumour may live and proliferate." 25 Connheim himself was of the view that "The possibility of the transport of particles from a tumour by the lymph-stream to the lymphatic glands and by the bloodstream into distant parts of the vascular system, is, it is true, unquestionable." 26

The unquestioning acceptance of the doctrine of metastasis by means of cancer cells (as against cancer juices) was also encouraged by observations which were not purely microscopical or experimental. For instance, in 1864 ERICHSEN reasoned-by means of analogy-that in the viscera cancer cells "are deposited just like pus-corpuscles in pyemia in these organs, where each cancer-celle forms the nucleus of a new growth." 27

${ }^{22}$ C. H. Jones, Cooper's Dictionary of Practical Surgery and Encyclopaedia of Surgical Science, ed. by S. A. Lane, London 1861, vol. 1, p. 392. See also T. Billroth, General Surgical Pathology and Therapeutics, trad. by C. E. HACKLEY, New York 1871, p. 554; and Edinburgh Med. J. 22 (1877) 1041.

${ }^{23}$ J. J. Woodward, On the Structure of Cancerous Tumors and the Mode in Which Adjacent Parts Are Invaded, Washington 1873, p. 10.

${ }^{24}$ Brit. Foreign Med.-Chir. Rev. 50 (1872) 117.

${ }^{25}$ Glasgow Med. J. 10 (1878) 330.

${ }^{26}$ J. Cohnheim, Lecture on General Pathology, trad. by A. B. McKeE, London 1889, p. 799.

${ }^{27}$ J. Erichsen, The Art and Science of Surgery, London 1864, 4th ed., p. 496. 
Likewise, the topographical distribution of secondary deposits was invoked in favour of cancer-cell carriage, for CoATs argued thus:

"As to the nature of the material which passes from the tumour, it must be either something dissolved in the juices, or else solid particles of some kind. Looking to a secondary cancerous infection of the peritoneum, we can hardly escape the conclusion that it is a finely divided solid. The secondary tumours are not regularly distributed over the peritoneal surface, but occur here and there or in groups, just as if solid particles had been carried and produced their effects where they got leave to lie. Then also it must be solid particles which are arrested by the lymphatic glands and give rise to the secondary tumours there, as it were by embolism. The probability is that the actual cells of the tumours are carried off and deposited at a distance." 28

In conclusion, it would appear that one of the last stands made against the growing acceptance of the cell theory of metastasis was that which took place in 1874 at meetings of the Pathological Society of London. In that year there were several discussions on cancer, the leaders of the different shades of thought contributing. ${ }^{29}$ Thereafter, although an occasional voice has been raised against metastasis by the agency of cells, ${ }^{30}$ the cell theory has held the field. ${ }^{31}$

28 J. Coats, A Manual of Pathology, London 1883, pp. 177-178.

29 Trans. Pathol. Soc. (London) 25 (1874) 287-402.

${ }^{30}$ R. BeLL, The Prevention of Cancer, London 1912, p. 55.

${ }^{31}$ New York Med. J. 48 (1888) 677; W. J. Walsham, Surgery: Its Theory and Practice, London 1889, 2nd ed., p. 63; J. Galloway, The Malignant Diseases of Serous Membranes, M. D. Thesis, Aberdeen University, 1892, p. 20; R. A. Willis, The Spread of Tumours in the Human Body, London 1952, p. 36.

From the Pathology Department of the University of Glasgow (Director: Prof. Dr. D. F. CAPPELL) 